\title{
UDC 661.842.091:661.333.002.84
}

E.O. Mikhailova ${ }^{1}, \mathrm{PhD}$, Assoc.Prof.,

V.O. Panasenko ${ }^{2}$, DSc, Prof.,

N.B. Markova ${ }^{3}$, Senior Researcher

${ }^{1}$ Simon Kuznets Kharkiv National University of Economics, 9-A Nauky Ave., 61166 Kharkiv, Ukraine; e-mail: eva.mikhaylova@ mail.ru

${ }^{2}$ State Research and Design Institute of Basic Chemistry (NIOCHIM), 25 Mironositskaya Str., 61002 Kharkiv, Ukraine

${ }^{3}$ National Technical University "Kharkiv Polytechnic Institute", 21 Bagaley Str., 61002 Kharkiv, Ukraine

\section{CALCIUM CARBONATE SYNTHESIS WITH PRESCRIBED PROPERTIES BASED ON LIQUID WASTE OF SODA PRODUCTION}

\begin{abstract}
Є.О. Михайлова, В.О. Панасенко, Н.Б. Маркова. Синтез карбонату кальцію із заданими властивостями на основі рідинних відходів содового виробництва. Перспективним напрямком у вирішенні екологічних проблем содової галузі є розробка маловідходних ресурсозберігаючих технологій, які полягають у переробці цінних компонентів відходів з одержанням товарних продуктів. Мema: Метою роботи $\epsilon$ встановлення оптимальних умов одержання карбонату кальцію із заданими властивостями 3 рідинних відходів содового виробництва. Матеріали і методи: Хімічно осаджений карбонат кальцію застосовується як наповнювач і повинен мати певні фізико-хімічні властивості. Для одержання продукту необхідної якості процес осадження карбонату кальцію проводили з дистилерної рідини, що є відходом виробництва кальцинованої соди і містить значну кількість іонів кальцію, і надлишкового маточного розчину виробництва очищеного гідрокарбонату натрію, до складу якого входять карбонатні та гідрокарбонатні іони. Результати: Встановлено залежність насипної густини і питомої поверхні осадів карбонату кальцію і ступеня його осадження від таких технологічних параметрів: способу змішування вихідних розчинів, концентрації і мольного співвідношення реагентів, температури і часу протікання реакції. Висновки: Визначено оптимальний режим процесу осадження і розроблено принципову схему виробництва карбонату кальцію, якість якого відповідає сучасним вимогам щодо високої дисперсності, низької насипної густини і розвиненої питомої поверхні продукту.
\end{abstract}

Ключові карбонат кальцію, хімічне осадження, відходи содового виробництва

E.O. Mikhailova, V.O. Panasenko, N.B. Markova. Calcium carbonate synthesis with prescribed properties based on liquid waste of soda production. A promising direction in solving of environmental problems of soda industry is the development of low-waste resourcesaving technologies, which consist in recycling of valuable waste components with obtaining the commercial products. Aim: The aim is to establish the optimal conditions for obtaining calcium carbonate with prescribed properties from liquid waste of soda production. Materials and Methods: Chemically deposited calcium carbonate is used as filler and should have certain physical and chemical properties. To obtain a product of prescribed quality the process of calcium carbonate deposition was performed of still waste liquid, that is the waste of calcium carbonate production and contain significant amount of calcium ions, and excessive production of the purified stock solution of sodium bicarbonate, which is composed of carbonate and hydrocarbonate ions. Results: The dependence of bulk density and specific surface area of calcium carbonate sediments and degree of deposition from such technological parameters are established: method of mixing the stock solutions, the concentration and molar ratio of reactants, temperature and reaction time. Conclusions: The optimal mode of deposition process is determined and the concept of production of calcium carbonate is developed. The quality of calcium carbonate meets the modern requirements of high dispersion, low bulk density and evolved specific surface of the product.

Keywords: calcium carbonate, chemical deposition, waste of sodium production.

Introduction. Soda production - one of the oldest in the world branches of chemical industry. In production, trade and in life under the name soda several products meet: ash soda - a waterless sodium carbonate $\mathrm{Na}_{2} \mathrm{CO}_{3}$; a purified sodium bicarbonate $\mathrm{NaHCO}_{3}$, often called as baking soda; caustic soda or sodium hydroxide $\mathrm{NaOH}$; crystal carbonate $\mathrm{Na}_{2} \mathrm{CO}_{3} \cdot 10 \mathrm{H}_{2} \mathrm{O}$ and $\mathrm{Na}_{2} \mathrm{CO}_{3} \cdot \mathrm{H}_{2} \mathrm{O}$.

The soda ash which use is characterized by a wide range of modern industries in which technological process she plays the main role (Fig. 1) has the greatest value for economy. The leader in its use is the silicate industry. In chemical industry a significant amount of soda is spent in processes of water and brines purification, for synthesis of various salts, dyes, some mineral fertilizers. In metallurgy the sodium carbonate is applied to receive some nonferrous metals, for desulphurization of cast iron and enrichment of uranium ores. The soda ash plays a significant role for pulp-and-paper, petrochemical and coke-chemical branches. Besides, it is used in production of the purified sodium 
bicarbonate which, in turn, is used in food, rubber and medical industries, and also for production of the caustic soda, irreplaceable for purification of oil and metal sodium preparation [1].

From the moment of independence of Ukraine acquisition three soda plants worked in the territory: in Sloviansk (Donetsk region), Lysychansk (Luhansk region) and Krasnoperekopsk (Crimea). Feature of soda production is its high need for raw materials and large tonnage of waste. So, for production of one ton of soda ash the $1.5 \mathrm{t}$ of table salt, $1.5 \mathrm{t}$ of limestone, $1.7 \mathrm{t}$ of conditional fuel are spent, and $8 \mathrm{t}$ of waste are formed. Therefore, such positioning of the enterprises is explained by direct proximity to a source of raw materials, existence of the necessary territory for warehousing of waste, and also the convenient traffic intersection. In due time, the domestic manufacturers completely provided domestic market with necessary products of soda. Besides, domestic soda was one of the best and competitive in the European market and occupied about $2.5 \%$ of its volume.

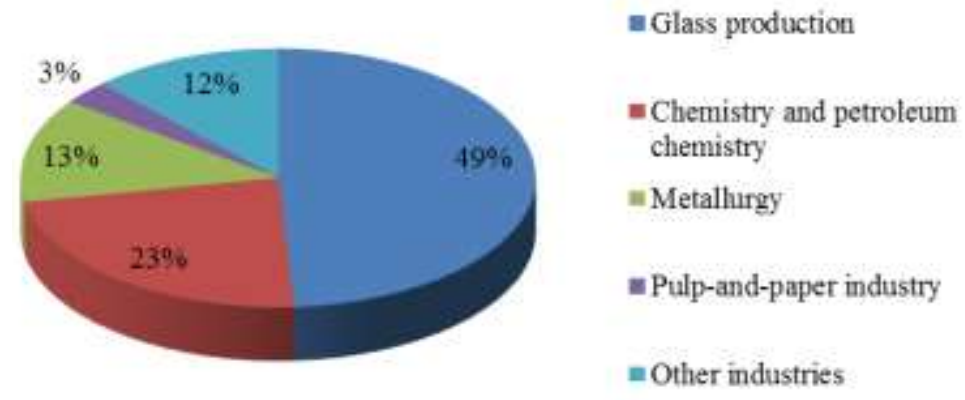

Fig. 1. Structure of soda ash consumption in Ukraine

Now need of Ukraine for soda ash is $300 \ldots 350$ thousand tons per year. On the place of the Sloviansk and Lysychansk enterprises there are only industrial platforms, and supply of soda from the Crimea to continental Ukraine became extremely unstable. Therefore, the domestic consumers who are using soda as raw materials are forced to import it from other countries.

In the emerged situation expedient and, the main thing, economically reasonable becomes creation in Ukraine of new production of soda ash. Dovgaliuk [2], the director of the state institute of NIOCHIM (Kharkiv), considers that the optimum place for placement of the soda enterprise is the platform of the former plant in Sloviansk. The reason of such choice consists in that unlike Lysychansk, necessary constructions have remained here - brine extraction facility, a chalk-pit and the sludge collector, that will allow to reduce costs of restoration of the plant.

Besides positive sides of revival of soda production in Ukraine, it is impossible to forget about ensuring ecological safety of this branch. In Ukraine, as well as in the majority of the countries of the world, soda ash is received by ammonia method Solvay which has a high level of the technological process organization and rather high economic efficiency. At the same time, shortcomings of this method are low extent of use of raw materials, high power consumption and existence of significant amount of waste in the form of liquid, solid and gaseous substances. If gas emissions contain components within maximum permissible norms, then they are released into atmosphere. At the same time, liquid and solid waste of production completely dumps in sludge collectors - "the white seas" which occupy more than $300 \ldots 350$ hectares of the land plots in regions of arrangement of the soda plants $[1,3]$.

Settlers-sludge collectors not only occupy considerable land areas, but also are sources of continuous impact on water objects and the soil. Slurry waters have high alkaline reaction of the environment ( $\mathrm{pH}$ value is up to 12.0) and high mineralization due to the content of soluble ions (chlorides, sulfates, sodium, calcium, ammonium) that has high migratory ability. The arrangement of accumulators within settlements and in regions of large waterways worsens a sanitary and hygienic and ecological situation and threatens health of the population.

Processing of a wastage with receiving new products on its basis, which have wide application in the national economy, allows to reduce the amount of the wastage coming to the sludge collector and to lower anthropogenous load of soda production on the biosphere. Results of estimation of toxico - 
logical impact of slimes and liquids of soda production on various test-objects (Ceriodaphnia affinis, Paramecium caudatum) received by Samutin [4] showed that this wastage refers to the IV class of hazard (are low-hazard for the environment) that is justification for the possible directions of their use.

Way of solution of ecological problems of soda enterprises are various and each of them deserves an attention and comprehensive study [5...8].

According to authors of article, the perspective direction of utilization of enterprises effluent for production of soda is obtaining a marketable product - chemically besieged calcium carbonate which finds wide application as an excipient for creation of various composites [9]. Production of chemically besieged calcium carbonate in Ukraine is also absent now.

The aim of the work is to establish the optimal conditions for obtaining calcium carbonate with prescribed properties from liquid waste of soda production.

Materials and Methods. As a part of almost all composites the excipients are widely used. They are various on chemical composition and origin natural and the synthetic materials and are entered into composition structures for reduction in cost or collimating of particular operational properties to them. One of the most widespread types of excipients is a fine-grained chalk (calcium carbonate). It finds application in production of dry structural blends, finishes, plasters, coating compositions, plastic, rubber, paper, cable production. Calcium carbonate is received in two ways:

- by refinement of breeds and sedimentary deposits (naturally occurring or natural calcium carbonate);

- by chemical deposition (chemically besieged calcium carbonate).

Particles of natural excipients, including with high level of micronization are, as a rule, significantly larger, than of the products obtained by deposition. They also concede on purity level, whiteness and content of the main substance that significantly limits the field of their application.

Obtaining of product by chemical deposition allows improving the quality of excipient (Table 1).

Table 1

The main rates of chemically besieged calcium carbonate quality

\begin{tabular}{|c|c|c|}
\hline \multirow{2}{*}{ Rate } & \multicolumn{2}{|c|}{ Value } \\
\hline & $1^{\text {st }}$ quality & $2^{\text {nd }}$ quality \\
\hline Whiteness, \%, not less & 93 & No norm. \\
\hline \multicolumn{3}{|l|}{ Containing, mas. \%: } \\
\hline - carbonates of $\mathrm{Ca}$ and $\mathrm{Mg}$ in terms of $\mathrm{CaCO}_{3}$, not less & 98.5 & 97 \\
\hline — the free alkali in terms of $\mathrm{CaO}$, at most & 0.03 & 0.05 \\
\hline — moisture, at most & 0.5 & 1.5 \\
\hline —other impurities, at most & 0.1 & 0.3 \\
\hline Bulk weight, $\mathrm{g} / \mathrm{cm}^{3}$, at most & 0.25 & 0.4 \\
\hline Specific surface area, $\mathrm{m}^{2} / \mathrm{g}$, not less & \multicolumn{2}{|c|}{$6 \ldots 12$} \\
\hline
\end{tabular}

Chemically besieged calcium carbonate is generally obtained by the "limy" way using calcium hydroxide suspension carbonization by gaseous carbonic oxide (IV) [10]. However, for a number of reasons, this method does not allow to obtain a product of necessary quality.

It is possible to receive calcium carbonate with necessary properties if to use the clear solutions containing well soluble salts of calcium as raw materials. From this point of view the technology of receiving besieged $\mathrm{CaCO}_{3}$ based on wastage of the soda enterprises is of the considerable interest: the still waste liquid which is formed during the obtaining of soda ash, and also the excess mother solution obtained as a result of the cleared sodium bicarbonate manufacture process. These substances do not find further use in the next cycles and are pumped over in settlers stores.

The qualitative composition of a wastage according to production terms of the corresponding soda productions (Table 2) allows receiving a calcium carbonate deposit using the equations of reactions:

$$
\begin{gathered}
\mathrm{CaCl}_{2}+\mathrm{Na}_{2} \mathrm{CO}_{3}=\mathrm{CaCO}_{3} \downarrow+2 \mathrm{NaCl}, \\
\mathrm{CaCl}_{2}+2 \mathrm{NaHCO}_{3}=\mathrm{CaCO}_{3} \downarrow+2 \mathrm{NaC} 1+\mathrm{H}_{2} \mathrm{O}+\mathrm{CO}_{2} \uparrow .
\end{gathered}
$$


Chemical composition of a wastage of soda production

\begin{tabular}{c|c|c|c|c|c}
\hline \multicolumn{3}{c|}{ The clarified still waste liquid } & \multicolumn{3}{c}{ Excess mother solutions } \\
\hline Composition & \% mas. & $\mathrm{g} / \mathrm{dm}^{3}$ & Composition & \% mas. & $\mathrm{g} / \mathrm{dm}^{3}$ \\
\hline $\mathrm{CaCl}_{2}$ & 12.90 & 149.77 & $\mathrm{NaHCO}_{3}$ & 12.95 & 145.25 \\
\hline $\mathrm{NaCl}$ & 6.01 & 69.78 & $\mathrm{Na}_{2} \mathrm{CO}_{3}$ & 4.72 & 52.99 \\
\hline $\mathrm{CaSO}_{4}$ & 0.50 & 5.81 & $\mathrm{NaCl}$ & 0.47 & 5.26 \\
\hline $\mathrm{MgCl}_{2}$ & 0.21 & 2.44 & & & \\
\hline $\mathrm{NH}_{3}$ & 0.0034 & 0.040 & & & \\
\hline
\end{tabular}

During an experiment the dependence of bulk weight and a specific surface area of depositions of calcium carbonate, and also its extent of sedimentation on the following technological parameters were studied by authors: way of mixture of initial solutions, concentration and molar ratio of reagents, temperature and time of reaction behavior.

The research of influence of the interfusing sequence of initial solutions was conducted by adding of the clarified still waste liquid to an excess mother solution ( $\mathrm{SWL} \rightarrow \mathrm{MS}$ ), dispensing of a mother solution to still waste liquid (MS $\rightarrow$ SWL) and at simultaneous interfusing of initial solutions (MS $\downarrow S W L \downarrow$ ).

Different concentration of $\mathrm{CaCl}_{2}, \mathrm{NaHCO}_{3}, \mathrm{Na}_{2} \mathrm{CO}_{3}$ substances in initial solutions it was created by their dilution at $1.25 ; 1.5 ; 1.75 ; 2 ; 2.25$ times.

Dependence of the product quality on the molar charge ratio was established by creation of stoichiometric excess of one reagent concerning another. So, in the beginning, used the surplus of ions of $\mathrm{Ca}^{2+}$ equal to $1.2 ; 1.4 ; 1.6 ; 1.8 ; 2$, and then - surplus of ions of $\mathrm{HCO}_{3}{ }^{-}$and $\mathrm{CO}_{3}{ }^{2-}$.

Deposition of calcium carbonate was carried out in the range of temperatures from 70 to $90^{\circ} \mathrm{C}$.

The lower temperature bound of process was chosen according to solubility polytherm in the $\mathrm{Na}_{2} \mathrm{CO}_{3}-\mathrm{NaHCO}_{3}-\mathrm{H}_{2} \mathrm{O}$ system, and also taking into account a possibility of future technology implementation of obtaining of chemically besieged calcium carbonate in the conditions of already existing productions of the corresponding soda products.

The analysed time of reaction behavior was from 1 to 10 minutes that corresponds to results of the state-of-the-art review of references.

For carrying out researches the experimental assembly (Fig. 2) was created. Deposition of $\mathrm{CaCO}_{3}$ was carried out in the reactor-precipitator 3, where in the given temperature mode the initial solutions entering from tanks 1 and 2 mixed up at continuous hashing of a reaction mixture ( $\mathrm{Re}=16000$, $500 \mathrm{rpm})$. Dispensing of reagents was controlled using flowmeters 7. The obtained deposit was filtered by a vacuum filter 4 from a mother solution, in the same place was washed using hot distilled water from chlorine ions, and then dried up at a temperature of $105 \ldots 110^{\circ} \mathrm{C}$ in a drying chamber up to the constant weight. Further, the qualitative and quantitative analysis of obtained filtrate and deposition of calcium carbonate was carried out.

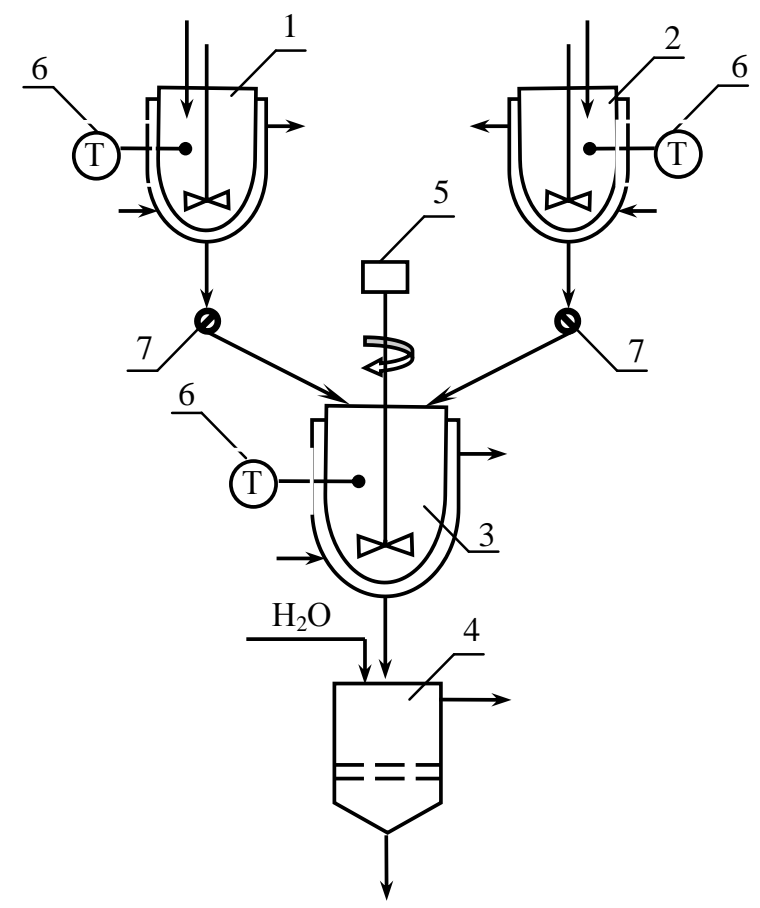

Fig. 2. Scheme of the experimental assembly: 1, 2 - temperature-controlled collections of initial solutions; 3 -temperature-controlled reactorprecipitant; 4 - vacuum filter; 5 - tachometer; 6 -mercurial thermometer; 7 -flowmeter 
Results. The analysis of the experimental data of dependence of calcium carbonate properties on concentration of reagents showed that a dilution of initial solutions leads to receiving of $\mathrm{CaCO}_{3}$ depositions with high bulk weight and undeveloped specific surface area. It is possible to reach increase in concentration of solutions by evaporation that demands the considerable energy cost. Therefore, the solution of use of initial solutions with concentration with which they are formed in the corresponding productions is optimum.

During researches it was established that the molar charge ratio slightly influences on quality of the received calcium carbonate. Besides, the amounts of an excess mother solution which are formed in production of the cleared sodium bicarbonate it is, much less, than it is necessary for complete utilization of the corresponding amounts of the clarified still waste liquid of soda ash production. Thus, it is possible to receive a product with necessary physical and chemical properties in the conditions of a stoichiometric relationship of initial reagents that will allow using more rationally the corresponding wastage as raw materials.

Researches results of bulk weight dependence of calcium carbonate from a way of mixture of initial solutions showed (Fig. 3) that for receiving of deposit with bulk weight at least $0.4 \mathrm{~g} / \mathrm{cm}^{3}$, simultaneous adding of reagents to the reactor precipitant is the most acceptable. Other consequence of solutions interfusing leads to increase in bulk weight. Also it was established that in the conditions of elevated temperatures the calcium carbonate deposit with smaller value of bulk weight is formed. Increase in time of a precipitation process, on the contrary, promotes receiving a product with higher rate of bulk weight.

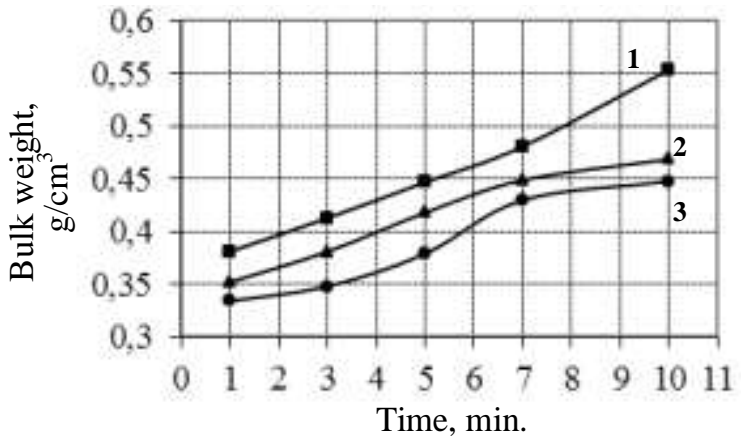

$a$

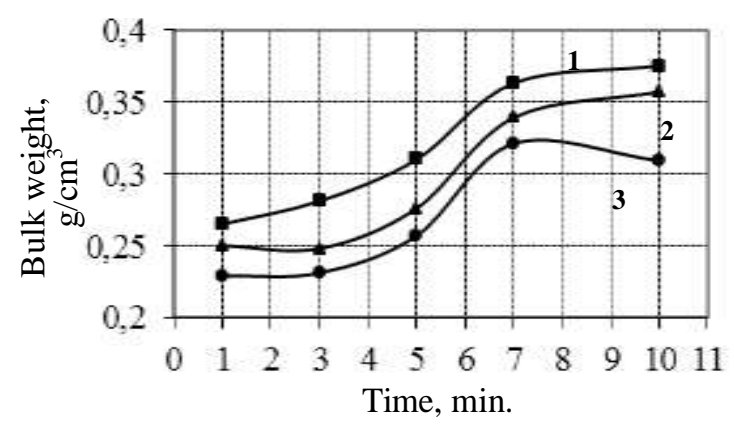

$c$

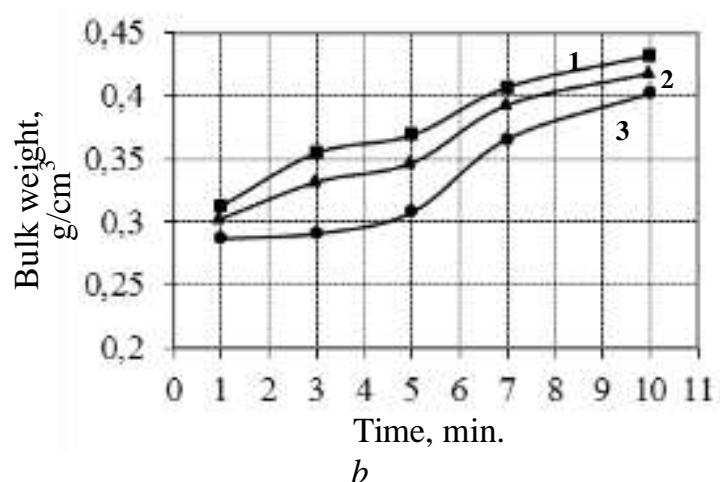

Fig. 3. Dependence of bulk weight of calcium carbonate on a way of mixture of initial solutions $(1-S W L \rightarrow M S ; 2-M S \rightarrow S W L ; 3-M S \downarrow S W L \downarrow)$, on time and temperature

$\left(a-50{ }^{\circ} \mathrm{C}, b-70{ }^{\circ} \mathrm{C}, c-90{ }^{\circ} \mathrm{C}\right)$

Researches of temperature effect and time of precipitation process in the conditions of simultaneous interfusing of initial solutions on a specific surface area of exemplars of calcium carbonate showed the exacting nature of the obtained dependences (Fig. 4).

It can be explained with the fact that at the beginning of precipitation process a large number of shallow particles of calcium carbonate is formed that it leads increase of a specific surface area. And, the process temperature is higher, the quicker there is an achievement of the maximal value. By results of the experimental data it is possible to draw a conclusion that it is possible to obtain calcium carbonate with necessary value of specific surface area at any temperature, however time of precipitation process should 
not exceed 5 minutes. It was established that in all area of the studied temperatures the functions of specific surface area curves have an extremum (point of a global maximum).

One of the key technological parameters influencing on effectiveness of raw materials use is extent of its sedimentation. The dependence of sedimentation extent of calcium ions on time and temperature of process at simultaneous mixture of still waste liquid with excess mother solution (Fig. 5) is established by authors during the experiment. Results of researches demonstrate increase in the given rate at increase of (behavior) process temperature that it is possible to explain with decrease of calcium carbonate solubility in these conditions. It is known that sodium chloride in which solution there is a sludging, increases solubility of calcium carbonate. However, according to the equation of "salt" effect it is established, that both in clear solvent (water), and in sodium chloride solution solubility of calcium carbonate decreases with increase of temperature.

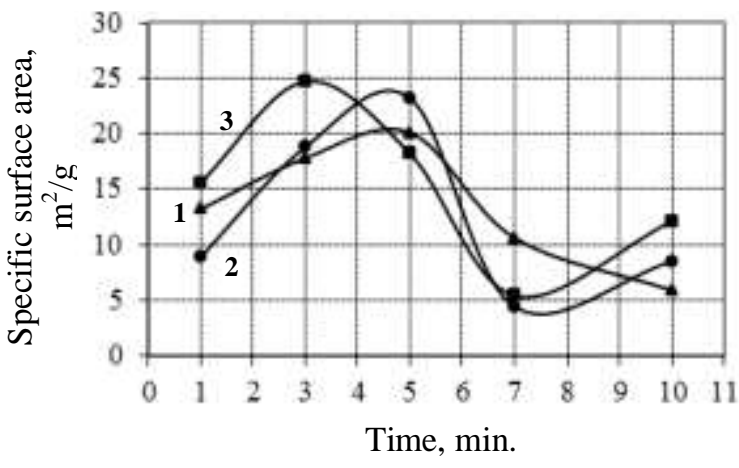

Fig. 4. Dependence of a specific surface area of calcium carbonate on time and temperature $\left(1-50{ }^{\circ} \mathrm{C}, 2-70{ }^{\circ} \mathrm{C}, 3-90^{\circ} \mathrm{C}\right)$

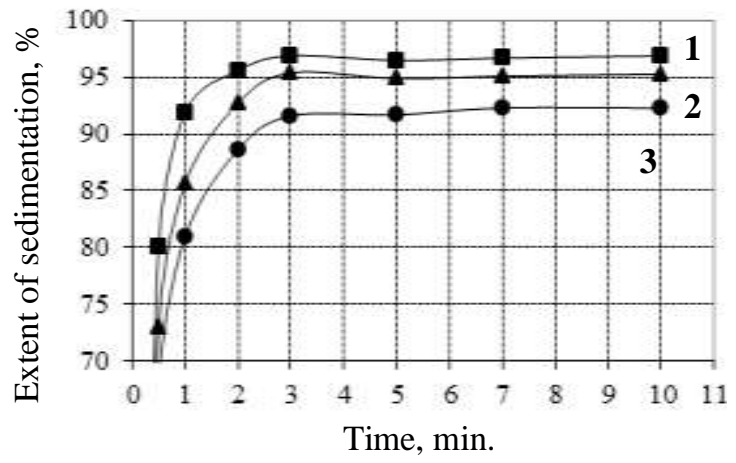

Fig. 5. Dependence of sedimentation extent of calcium carbonate on time and temperature $\left(1-90{ }^{\circ} \mathrm{C}, 2-70{ }^{\circ} \mathrm{C}, 3-50{ }^{\circ} \mathrm{C}\right)$

Conclusions. By results of the conducted researches the optimum process conditions of calcium carbonate deposition is defined. It is established that to receive the product meeting requirements to this excipient it is possible at simultaneous interfusing of the clarified still waste liquid and an excess mother solution in the conditions of a stoichiometric ratio of reactants at a temperature of $80 \ldots 85^{\circ} \mathrm{C}$ within no more than 3 minutes. In this case bulk weight of a product will make at least $0.24 \mathrm{~g} / \mathrm{cm}^{3}$, its specific surface area - not less than $23 \mathrm{~m}^{2} / \mathrm{g}$, and extent of sedimentation - not less than $96.5 \%$.

Authors also developed the concept scheme of chemically besieged calcium carbonate production which provides predefining of still waste liquid from solids, interfusing of initial solutions in the given technological mode, filtration and washing of the obtained deposit till complete removal of chlorine ions, and then drying, crushing, sieving and casing of a finished stock. The offered way gives the possibility to obtain no more than 5 thousand tons of synthetic calcium carbonate a year that it is not enough for requirements of domestic market of Ukraine. The outputs are limited to the actual number of the waste which is formed in production of the cleared sodium bicarbonate. To increase the efficiency of technology of Mikhaylova, etc. [11] it was offered to use solution of soda ash as precipitant instead of mother solutions or along with them.

Thus, the offered way of receiving chemically besieged calcium carbonate based on effluent of soda production promotes not only utilization of valuable components of this waste and decrease of dumping of highly mineralized solutions into sludge collectors, but also receiving the qualitative product which have found wide application in various industries which consumption steadily increases over the last few years.

\section{Література}

1. Ткач, Г.А. Производство соды по малоотходной технологии: монография / Г.А. Ткач, В.П. Шапорев, В.М. Титов. — Харьков: ХГПУ, 1998. — 429 с. 
2. Украина будет с содой [Електронний ресурс] / И. Довгалюк // Государственное учреждение Государственный научно-исследовательский и проектный институт основной химии. — 2016. Режим доступу: http://niochim.kharkov.ua/?q=ru/news/ukraina-budet-s-sodoi (Дата звернення: 15.03.2016).

3. Steinhauser, G. Cleaner production in the Solvay Process: general strategies and recent developments / G. Steinhauser // Journal of Cleaner Production. - 2008. - Vol. 16, Issue 7. — PP. 833-841.

4. Санитарно-гигиеническая оценка отходов содового производства / Н.М. Самутин, Я.И. Вайсман, Л.В. Рудакова [и др.] // Гигиена и санитария. — 2013. - № 2. - С. 30-33.

5. Манойло, Е.В. Применение отходов содового производства / Е.В. Манойло, Ю.А. Манойло, В.Ф. Моисеев // Восточно-Европейский журнал передовых технологий. — 2010. — № 6/6 (48). — C. $13-17$.

6. Gur, N. Utilization of soda ash plant solid wastes in manufacture of cement / N. Gur, Y. Aktas, E. Oztekin // Elixir Cement and Concrete Composites. - 2012. — Vol. 47. — PP. 8866-8873.

7. Магеря, Я.О. Применение выпарных аппаратов при получении хлорида кальция из отходов содового производства /Я.О. Магеря, В.П. Михайличенко, С.А. Гринь // Восточно-Европейский журнал передовых технологий. - 2013. - № 1/6 (61). - С. 10-13.

8. Utilization of distiller waste from ammonia-soda processing / T. Kasikowski, R. Buczkowski, B. Dejewska, et al. // Journal of Cleaner Production. - 2004. - Vol. 12, Issue 7. — PP. 759-769.

9. Białowicz, K. Precipitation of calcium carbonate in the presence of urea at $293 \mathrm{~K}$ and $343 \mathrm{~K} /$ K. Białowicz, U. Kiełkowska // Polish Journal of Chemical Technology. — 2014. — Vol. 16, Issue 2. PP. 95-98. DOI:10.2478/pjct-2014-0037

10. Курта, С.А. Наповнювачі - синтез, властивості та використання / С.А. Курта. - ІваноФранківськ: Прикарпат. нац. ун-т ім. Василя Стефаника, 2012. - 295 с.

11. Спосіб утилізації рідинних відходів виробництва кальцинованої соди / С.О. Михайлова, Н.Б. Маркова, І.В. Багрова [та ін.] // Збірник наукових праць ДУ «НІОХІМ»: Хімія і технологія виробництв основної хімічної промисловості. — 2013. - Т. 77. — С. 76-81.

\section{References}

1. Tkach, G.A., Shaporev, V.P., \& Titov, V.M. (1998). Production of Sodium Carbonate by a Low-Waste Technology. Kharkiv: H.S. Skovoroda Kharkiv National Pedagogical University.

2. Dovgaliuk, I. (2016). Ukraine will be with Soda. State Research and Design Institute of Basic Chemistry. Retrieved from http://niochim.kharkov.ua/?q=en/news/ukraine-will-be-soda

3. Steinhauser, G. (2008). Cleaner production in the Solvay Process: general strategies and recent developments. Journal of Cleaner Production, 16(7), 833-841. DOI:10.1016/j.jclepro.2007.04.005

4. Samutin, N.M., Vaisman, Ya.I., Rudakova, L.V., Kalinina, E.V., Glushankova, I.S., \& Batrakova, G.M. (2013). Sanitary and hygienic assessment of waste of soda production, Hygiene and Sanitation, 2, 30-33.

5. Manoilo, E., Manoilo, Yu., \& Moiseev, V. (2010). Application of wastes of soda production. EasternEuropean Journal of Enterprise Technologies, 6(6), 13-17.

6. Gur, N., Aktas, Y., \& Oztekin, E. (2012). Utilization of soda ash plant solid wastes in manufacture of cement. Elixir Cement and Concrete Composites, 47, 8866-8873.

7. Magerya, Y., Mihaylichenko, V., \& Grin, S. (2013). Application of evaporator getting the calcium chloride from waste soda production. Eastern-European Journal of Enterprise Technologies, 1(6), 10-13.

8. Kasikowski, T., Buczkowski, R., Dejewska, B., Peszyńska-Białczyk, K., Lemanowska, E., \& Igliński, B. (2004). Utilization of distiller waste from ammonia-soda processing. Journal of Cleaner Production, 12(7), 759-769. DOI:10.1016/S0959-6526(03)00120-3

9. Białowicz, K., \& Kiełkowska, U. (2014). Precipitation of calcium carbonate in the presence of urea at 293 K and 343 K. Polish Journal of Chemical Technology, 16(2), 95-98. DOI:10.2478/pjct-2014-0037

10. Kurta, S.A. (2012). Fillers - Synthesis, Properties, and Application. Ivano-Frankivsk: Vasyl Stefanyk Precarpathian National University.

11. Mikhailova, E.O., Markova, N.B., Bagrova, I.V., Gavrish, Y.G., \& Panasenko, V.A. (2013). A method of utilization of soda ash plant effluent. NIOCHIM Collected Works, 77, 76-81. 